\title{
THE TROUBLE WITH NIGERIAN UNIVERSITIES: BOGUS POLICY AND SPECULATIVE IDEOLOGY
}

AMAECHI UDEFI

(Received 26 April 2014; Revision Accepted 6 June 2014)

\begin{abstract}
There is no gainsaying the fact that Nigerian public universities and no less privately owned universities are facing a lot of challenges. Such problems that now characterise our universities include indiscipline, poor funding and inadequate facilities, examination malpractices, demonstration and rioting, secret cult activities, drug addiction, sexual immorality, theft, corruption and maladministration to mention just a few. Added to this is the problem of policy inconsistencies, mis-match and lack of a well articulated ideology that will underpin Nigerian educational system and ultimately stimulate national development and growth.

The paper attempts to show, among others, that the challenges confronting contemporary Nigerian Public Universities do not lie on the alleged abdication of functions by lecturers. Rather the problem lies squarely on government's insensitivity in terms of proper funding and provision of facilities, coupled with policy mis-match and ideology are responsible for the problems in the University subsystem and education in general. An unwavering commitment by the government and all the stakeholders to the goal of education and the deployment of moral education provide the best option for the resolution of the myriad of challenges facing Nigerian public universities.
\end{abstract}

KEYWORDS: Moral Education, Indiscipline, University, Virtue Ethics, Policy

\section{INTRODUCTION}

There is a general apprehension by lecturers, guardians, educators, and even in government circles about the problem of indiscipline among students of tertiary institutions. This problem seems to be accentuated by the vicious attacks and menace of secret cult members in institutions of higher learning in the country. As a result, especially of the latter, there is a general air of insecurity of life and property in the University community. But the question that looms large is: why is there a breakdown in the standard of discipline in the tertiary institutions?, and why do students now more than ever before engage in secret cult activities and use same to wreak unmitigated havoc on their fellow students? In order to answer these questions, we only need to look at the nature of the Nigerian society, because no school exists in a vacuum, that is to say that, the school, as a sub-system of the larger society, must necessarily reflect the societal values and norms.

The point being made here is that the school mirrors what goes on in the society whether positive or negative. Infact, social analysts have recognized that the kind of values a particular society holds must obviously creep into its school system. Hence it is advised that the penchance by some people to blame the causes of indiscipline on the teachers and students alike does not take us far enough. This is because the root cause lies elsewhere society. Perhaps this is what Ajayi (1990, p.20) intends when he says:

A child is bound to be a problem child in the school if he comes from a broken home or a home where honesty is not cherished, or a home where he lacks love and affection. By the same token, a

Amaechi Udefi, Department of Philosophy, University of Ibadan, Ibadan, Nigeria. 
society that condones' all ills.., is bound to transfer these ills to the school system.

However to claim otherwise does not in any way suggest that both teachers and students should be absolved from blame. Rather it is that once the real causes have been identified, we are halfway into solving the problem, The post-civil war period in Nigeria could be characterised as a period of reconstruction and re-orientation in the areas of socio-economic and value orientation of the people just emerging from the dislocating and devastating effects of the unfortunate thirty months' of fratricidal war. During this period, various acts of indiscipline such as corruption, armed banditry, vandalism, embezzlement and extortion, apparently to make up for the losses incurred during the war, were a common feature. The impression should not be created here that indiscipline first started in Nigeria in the interwar periods. It in fact predates that period. But the problem seems to have reached an intolerable proportion in the 1980's and 1990's. During these periods, Nigeria could better be regarded as a shadow of her former self. There has been a serious and steady deterioration in the moral realm. This is characterised by excessive greed, political, economic and moral decadence, negative work ethic, drug and currency trafficking, advance fee fraud (popularly called 419), assassination, inflation of contracts etc. This scenario is captured by Maitama Sule (1987, p.11) when he said:

corruption has eaten deep into the fabric of our society so much so that it has now become a common denominator. Indiscipline has become the order of the day; honesty is no longer respected and appreciated; moral laxity and lack of financial integrity have both become rampant in our communities... People irrespective of their position are no longer ashamed to steal. In short, the institution of family has broken down and respect for elders which used to be a cardinal principle in our society is now at its lowest ebb.

But no society can ill-afford to maintain disciplined citizenry, because it is very fundamental to peaceful and orderly development of a country. In other words, no meaningful development can take place in an atmosphere of indiscipline and corruption. Thus there is an urgent need to extirpate and therefore reduce the ferocious effects of indiscipline and corruption in Nigeria.

To say this, however is to address the root cause of the problem which some social analysts like Otonti Nduka in his book The Roots of African Underdevelopment and Other Easys blame on different ideological or social formations prevalent in a society, capitalism, no less than socialism or neo-welfarism engenders certain social relations of production in which there is an emphasis on a private accumulation of wealth as the highest form of human activity; a centrally controlled wealth and a middle cause between the two respectively. Either system creates conditions for indiscipline and corruption. What has been adumbrated above is that indiscipline and corruption are not only a moral issue, but can also be explained by the socio-political and economic establishment of a society in a capitalist society like Nigeria, both the leaders and the followers lack a sense of responsibility for the general and supreme interest of the country. It is a situation where the rich gets richer and the poor is continually impoverished.

Ironically, this unfortunate situation cannot be explained by the scarcity of resources (for Nigeria is endowed with abundant resources), but rather inability to set priorities right and more so the tendency by a few to amass wealth without regard to established norms. Given this scenario, Nigerian leaders (past and present) have instituted programmes and pursued certain policies aimed at eradicating indiscipline with little result due to lack of iconic leaders who should serve as role models.

To be sure, General Olusegun 'Obasanjo's Jaji Declaration' of 1977, apparently borrowing a cue from General Murtala Mohammed, who made some bold attempts to fight indiscipline in Nigeria is one of such attempts. The solution to the problem in the wisdom of the government of Alhaji Shehu Shagari lay in his "Ethical Revolution" launched in 1982. Following the ouster of the Shagari regime in December 1983, the Buhari /ldiagbon regime that came to the stage came up with "War Against Indiscipline' with the acronym WAI, which perhaps was one of the well articulated programmmes to confront indiscipline and moral degeneracy in Nigeria. It was officially launched in March 1984. The Babangida administration which toppled the Buhari-Idiagbon regime in August 27, 1985 followed the footsteps of his 
predecessors and gave birth to National Orientation Movement (NOM) on July 5, 1986, which later metamorphosed into Mass Mobilization for Economic Recovery, SelfReliance and Social Justice (MAMSER), which was launched at the national level on July 25, 1987. The Abacha junta that eased out the feeble interim government of Chief Ernest Shonekan in November 1993, claimed that it was committed to the enthronement of a more disciplined, morally conscious Nigerian society. This idea informed the establishment of National Orientation Agency (NOA), an institutional machinery "charged by the government to preach to Nigerians the evils of corruption and indiscipline" (Umaru Aliyu 1996, p.1). What the Abacha administration did was to subsume the pre-existing programmes on moral consciousness and value orientation into his War Against Indiscipline and Corruption (WAIC). This latter is not too dissimilar, at least, conceptually and practically, with the former ones.

Having seen the state of affairs in Nigeria which we argue is characterised by indiscipline, corruption, dishonesty, greed, etc, and some of the institutional strategies aimed at combating them, we can say that the school as a subsystem of the society is not spared of the destructive effects of the societal ills. This point is hinged on the fact that the school, as a sub-set of the society, must" necessarily reflect the societal ethos of the environment in which it is located. What we see now is some sort of a carry-over of the societal values as highlighted into the school sub-system with the consequent erosion of the values of the school such as discipline. For instance, a father who diverts government property into his private use may unknowingly be teaching his innocent but curious children the act of stealing.

\section{The problem}

The interest in this study is informed by the researcher's experience of students' behaviours on campus for a period of six years. Although 'some critics may argue that six years is not enough to conclusively establish that students of institutions of higher learning are undisciplined or disciplined. But one can respond by saying that being disciplined or indisciplined is a matter of attitude and that since attitudes are not changed overnight, the six years period is certainly adequate to establish some conclusion about students and lecturers value orientation.

The other area that attracts the interest of the researcher is the often widespread impression by a cross-section of the populace that the students' poor academic performance and misbehavior are due to the lecturers' abdication of their statutory responsibility. The investigator feels that the time has come, as it were, to set the records straight. Again, it is claimed that the youths of today are tomorrow's leaders. If this claim is granted, then it behoves on the teachers and all those concerned with the molding of the young ones to confront the problem of indiscipline on the campuses head on, if we must bequeath to the country disciplined leadership. One final point that needs highlighting is that no serious academic work can take pace in an atmosphere of indiscipline. Besides, it must be acknowledged that no significant development can take place in an atmosphere where indiscipline pervades the entire fabric of a nation.

\section{Scope and significance}

This study will no doubt serve as a springboard for further researches geared towards ensuring peace and tranquility on our campuses. It will also enable lecturers to possibly determine objectively students' achievement tests in certain subjects. As the University of Ibadan has been chosen as case study, only four departments in three faculties will be covered and not all the departments and faculties because of time and financial constraints. The faculties and departments include;

$\begin{array}{lll} & \text { Faculty } & \text { Department } \\ \text { i. } & \text { Arts } & \text { History and Philosophy } \\ \text { ii. } & \text { Education } & \text { Teacher Education } \\ \text { iii. } & \text { Science } & \text { Physics }\end{array}$

Because of this narrowness in scope, the researcher does not pretend to make generalizations of the findings of this study. What the researcher does however is to open up new vistas for further researches wider in scope to cover as many campuses as possible.

It will be erroneous to claim that no serious study has been done on indiscipline in the Nigerian society. There are, in fact, numerous commentaries on the problem of indiscipline in the Nigerian schools and the ways to solve this "hydra-headed monster." But there seems to be a paucity of research on the same problem among students of tertiary institutions. This is due partly to the impression and perception that students of such institutions are mature and thus could not possibly exhibit acts of indiscipline since there is a correlation between maturity and discipline. But 
the opposite is the case. The strategy here therefore is to look at a few selected authors on indiscipline in the institutions of higher learning and the role education can play towards its eradication.

\section{Clarifying the Terms 'Indiscipline' and 'Discipline'}

Socrates (1469-399B.C) was perhaps the first philosopher to address the problem of 'akrasia' the Greek word, which literally translates incontinence, 'unrestraint', 'weakness of the will', 'moral weakness', 'lack of self-control and indiscipline.' It is claimed that Socrates introduced his popular moral puzzles, apparently to grapple with the problem (incontinence in our case). One of such puzzles is that knowledge is a necessary and sufficient condition for attaining virtue and hence doing the right thing. In other words, what Socrates is saying here reduces to something like if a person $Y$ knows that $X$ is wrong, he would refrain from doing $X$. 'But this Socratic dictum cannot be wholly correct or applicable in all situations because there are cases when people use their knowledge to do evil.

What Socrates attempts to do here is to substitute ignorance for indiscipline, since according to him all men want to be happy and hence would not want to do what will jeopardize their chances of attaining happiness. He (Socrates) however claims that if the contrary obtains, that is, knowing the good and yet doing the evil", that it is the result of ignorance (Protagoras 35 B.C). In any case, Socrates failed to show whether it is a case of ignorance in a situation where a man who perfectly believes that smoking is injurious to his health and decides to stop it, but only to resume smoking again after several temptations

This is certainly not a case of ignorance because the man (smoker) knows the benefit to his health if he gives up smoking, but lacks discipline, that is, the inner strength or power to act in conformity with his decision to stop smoking. Another example is a bank manager who, out of self-interest, defrauds his bank of millions of Naira, cannot be said to lack knowledge in the strict sense of the word, nor can he claim ignorance of the consequences of his action. What the bank manager lacks is certainly not knowledge but the will- power to subdue the dictates of his passion. Thus Socrates' attempts to dispose of indiscipline is not successful because there are cases which can properly be designated as cases of indiscipline rather than ignorance. Indiscipline therefore is the general lack of the capacity, the will-power that would dispose somebody to obey the rules or act in conformity with his deliberation to promote the good.

Ajayi (1990, p.3) considers lack of ethics, absence of morality or the breaking of norms as indiscipline. Essentially, it implies the lack of necessary training for the mind and body to develop and manifest appropriate and socially acceptable norm of behaviour, and thus various acts of indiscipline are injurious to the healthy growth and development of the society.

Jimoh (1987, p.15) recognizes the contextual or cultural specificity of the term indiscipline and its antonym discipline. In other words, what is considered as acts of indiscipline in one culture may not be so considered in another. This, according to him has made the concept so flexible such that it is used to refer to cases that would have passed for minor misbehavior or disruption. At any rate, no matter the situation or act that is so classified the term still "refers to 'those behaviours which are capable of impeding the achievement of the goals or objectives set for by an organization or institution".

Leaving aside indiscipline and turning to its opposite, discipline, one discovers that it does not easily lend itself to a definition. This is due partly because many people seem to confuse the term with punishment. Also, discipline is construed in a broad sense to mean "conformity to rules and unquestioned obedience and submission to a leader or the teacher". The former sense is what is regarded by some scholars as the negative concept of discipline" which treats it as a form of control from some external force or authority rather than as something that should come from within the individual" (Jimoh 1987, p.13). Adelayo Akinpelu (2005, pp.171-190) attempts a definition of discipline, which he says derives from its Latin origin disciples, 'which means to learn'. Akinpelu defines discipline as "any control mechanism deployed by the school authorities and the government in order to elicit some degree of control, conformity, obedience etc. to the rules, regulations, and laws of the institutions concerned'. (pp.126-133).

Ironically many people, including teachers and parents share the view that discipline is synonymous with punishment. In short, some school authorities and parents use 
excessive force, apparently to enforce discipline. But this could at best be regarded as "child abuse.'

This point is further elaborated by Mussen (1979, p.41) as:

some parents use excessive physical force in attempting to discipline children and in extreme cases, intentionally injure them, sometimes, severely or even fatally by beating, burning, pushing, throwing them down or suffocating them. In many instances, the parents' brutality serves no disciplinary purpose at all...

It is claimed that those that indulge in this kind of treatment work on the assumption that students or youth generally are mannerless, rude, depraved and believe that such erring students could be corrected by the infusion of discipline in them through coercion from a higher authority. But no amount of brutality or force can serve any disciplinary purpose. At best, it can only serve as a temporary palliative to deter them. It is however arguable whether such actually deters because experience has shown that people can be punished without being prevented from repeating the offence and without being made better. It is equally contentious whether the culprit himself or anyone else is necessarily deterred from committing the offence by punishment. The point being made here is that coercion is not necessarily a cure for indiscipline.

\section{Town and Gown or School and the Society Nexus}

In order to fully appreciate the problem of indiscipline on the campuses, it is important to examine the nature of the Nigerian society because as we stated above, the school is a subsystem of the larger society. In other words, there is an inter-play between the school and the society and the values of one impinge on the values of the other and vice versa. Thus, the values of the school influence the society and the attitudes of the society to a large extent permeate the school. In a society where there is a moral crisis, as it seems in Nigeria today, one expects nothing less from the school.

The contemporary Nigerian society is best described by political analysts like Chinua Achebe as a country with an unmitigated corruption and indiscipline. This assertion could hardly be faulted given the disorientation and depravity of our politicians and the entire citizenry. The country was once noted for her orderly, disciplined and positive value orientations especially before and shortly after independence. But things seemed to go awry especially during the First Republic and afterwards. Nigeria since then has been bedeviled by social ills of no mean proportion. There was an apparent lack of vision and no clear-cut philosophy of national development. The leaders and their retinue of sycophants have concentrated on amassing and looting the resources of the nation with 'impunity. The phenomenon of corruption in Nigeria perhaps prompted Achebe (1983, p.42) to say:

Nigeria is without any shadow of doubt one of the most corrupt nations in the world,... And so, from fairly timid manifestations in the 1960s, corruption has grown bold and ravenous as with each succeeding regime, our public servants have become more reckless and blatant.

The same sentiment is shared by the Report of the Committee on the War Against Indiscipline and Corruption (1993, p.21) when it said:

There is no denying the fact that indiscipline remains the bane of the contemporary Nigerian society, in spite of concerted efforts by past administrators to combat this debilitating malaise. Indeed today, indiscipline of all manifestations could be said to have assumed a disturbing dimension.

Thus, far, one can see that those societally approved values like discipline, honesty and even fear of God have been generally eroded by the pervasive effects of corruption generating values. But it is a generally accepted truism that no nation, no matter how richly endowed, can develop in an atmosphere of socio-economic and ethical anomie. For a nation to aspire to greatness, there has to be some set of national values which not only govern the life style and behavior pattern of the citizenry but also checks against unnecessary drift. Perhaps, this factor underlies the philosophy behind the mass mobilization efforts of our successive administrations. What is attempted here is to articulate the problems of contemporary society 
and the psyche of the Nigerian people and also see how such has filtered into the school system because the disciplinary problems in tertiary institutions, in a way, can be traced back to the larger society since no school can be isolated from its social environment. As the students are taught the virtues of discipline, honesty and dignity of labour, the society seems to be saying that "it does not matter much by what means individual Nigerians acquire their wealth and so, students in turn find it convenient to cheat in order to pass examinations." (Jimoh 1987, p.15). It is just like saying according to Madunagu (1983, p.12) that:

\begin{abstract}
...the parents' moral exhortation to a child not to steal is contradicted by generalized robbery especially by members of 'constituted authorities' who he has been taught to obey. He has to resolve these contradictions, and in most cases these are resolved in favour of his direct social experiences on account of their more forceful impact on him.
\end{abstract}

The point being stressed here is that most of the attitudes and behaviours of students in school can be traced to the societal influences on them. This underscores the need for societies to develop positive values that will lead to the achievement of national development.

If the problem of indiscipline persists, according to Lai Olurode (2004, p.14), what we will have is,

Intellectual atrophy which in turn
deepens undevelopment and
dependence... if the University fails to
deal with the problem, then hoodlums
would take over the conduct of
examinations and the award of degrees.

The problem of indiscipline and other social vices seem to be exacerbated by the government's reluctance in funding education even up to half of $26 \%$ as recommended by UNESCO to enable them cope with contemporary challenges of higher education. This is true of what Ebon $\mathrm{E}$ said as quoted by Aduke Adebayo (2005, p.18) that,

Nigerian Universities are under siege of decay. There are no facilities for effective practice for students in most of our campuses... most of these equipment are either not there and if they are there, they are not functioning and money is not coming...

\section{On Policy, Ideology and Virtue Ethics}

One of the challenges of Nigerian universities is the inability of the government to consistently implement its policy on education and the lack or absence of ideology. Before proceeding, let us examine however sketchily, what policy is. According to some scholars and political analysts, a policy option, which is a byproduct of a decision-making process, is usually evolved to address certain problems confronting individuals, society, organization agencies etc. At this stage, the policy is like a guide or charter or plan of action, which is stated as a proposal. This is perhaps the intention of Sharkansky (1978: p.7) when he said;

Policy can refer to a proposal, an ongoing programme; or the goals of a programme, major decisions or the refusal to make certain decision.

Similarly, a 'policy, according to Jenkins (1978: p.20) is;

A set of inter-related decisions by a political actor or group of actors concerning the selection of goals and the means of achieving them within a specified situation where those decisions should in principle be within the power of those actors to achieve.

What is noticeable in the above definitions is that a policy must involve the formulation stage, implementation stage, and evaluation stage.

It is instructive to note that policies are as many as there are problems or issues to address by the government. Such policies, according to Olaniyi (1998: p.14) are designed to affect a particular target population in a geo-politically defined entity". Thus there are policies relating to education, health, agriculture, economy, population, culture etc. The interest of this paper is on educational policy, which concerns policies affecting education in general.

The National Policy on Education, which was a by-product of many struggles and agitations by frontline nationalists and statesmen like Herbert Macaulay, Nnamdi Azikwe, Obafemi Awolowo, Alvan Ikoku amongst others, was 
intended to evolve a Nigerian brand or model of educational system different from the colonial (British) imposed system. Prior to this, the colonial system of education was geared towards training Nigerians on how to read, write and solve arithmetic with no emphasis on professional and vocational studies. However, the orientation began to change with the establishment of Yaba Higher College (now Yaba College of Technology) in 1934 and University College, Ibadan (now University of Ibadan) in 1948 with their curricula reflecting the needs of the country. The NPE (for short), which has undergone series of revision with the latest being 2004 edition is intended by the Federal Government "as a tool or way of achieving that part of its national objectives", (Olaniyi, 1998: p.113) as contained in the Second National Development Plan (19701974). The Second National Development Plan was borne out of the need to reconstruct the economy that was destroyed during the Nigerian Civil War. The plan encapsulates five main national objectives namely;

1. A free and democratic society

2. A just and egalitarian society

3. A United, strong and self-reliant nation

4. A great and dynamic economy

5. A land of bright and full opportunities for all citizens (FGN, 2004, p.7).

Now, the Federal Government affirms and believes that one of the ways of realizing the above national objectives is through the instrumentality of education. Hence, it recognizes that education is an "instrument par excellence for effecting national development" as well as "dynamic instrument of change" (Osokoya 1989: p.99). Again, Government notices that our national education system if it is to be meaningful should promote and inculcate in her citizens some positive values, which will effectively reinforce the five main national objectives stated above. These include,

1. Respect for the worth and dignity of the individuals.

2. Faith in man's ability to make rational decisions.

3. Moral and spiritual values in interpersonal and human relations.

4. Shared responsibility or the common good of society.

5. Respect for the dignity of labour and

6. Promotion of the emotional, physical and psychological health of all children (FGN 2004; p.7).
Ideology, composed of ideas and focusing on the state, is a belief system that is taken to be universal and absolute truth by its advocates. For Hoffman and Graham (2006: p.3).

To call a set of beliefs ideological is merely to argue that ideas are organized for a particular statist purpose, they form the basis of a political movement... whether this is a movement we approve of or not. The term is generally used to denote a belief system.

Similarly, Dipo Irele (1993: p.15) defines ideology as a system of political and social beliefs that embodies values and ideals about man, society and the state". What can be gleaned from the above is that many movements and perspectives can be called ideological in so far as they are held by groups or classes and are capable of "impacting upon society and moving people into action in relation to the state" (Hoffman and Graham, 2006: p.3).

It is important to note that the two dominant schools of thought in relation to the discourse of ideology are materialism and idealism. In other words, the various forms of ideologies, be it capitalism, socialism, liberalism, conservatism, among others, would have leaned on either or a mixture of both. These two traditions have been explicated by Engels as quoted by Dipo Irele thus;

The great basic question of all philosophy... is that concerning the relation of thinking and being. The answers which the philosophers gave to this question split them into two great camps. Those who asserted the primacy of thinking to nature and, therefore, in the last instance, assumed world creation in some form or other ... Hegel, for example... comprised the camp of idealism. The others, who regarded nature as primary, belong to the various schools of materialism ... (p.16).

We do not intend to go into any detailed elaboration of ideology and contentious issues surrounding it, but only to show its relation to the policy of education in Nigeria. For Karl Marx, ideology, particularly from the idealist view, which places consciousness and thought as primary to matter, is regarded as "false consciousness". By this, Marx meant, according Irele, that: 
It is a reflection of a wrong world which, though adequately depicting social existence, does not reveal its wrongness; and in so far as that is true, it serves to conceal the actual meaning of social conduct, rather than reveal it, (p. 21).

The point here is that ideology, comprised of ideas and beliefs, are deliberately constructed by the ruling class to mask the true historical realities of the society in order to achieve some desired goal or end (Marx and Engels, 1970: p.47). This point is reiterated by Irele thus;

In any social formation the ideology of the ruling class reflects the prevailing mode of production of a particular society. However, it is "presented as the ideology of the whole society through the ideological apparatus of the state,. The ideas of the ruling class express its class interest, they are the ideas of its dominance. (p.18).

An illustration of this scenario is given by Hoffman and Graham (2006: p.3) when they said that "bourgeois ideologies may support the proposition that it is natural for people to exchange products and for the thrifty to accumulate wealth, but these beliefs merely reflect' the interests of the capitalist class". Hence, in their opinion, unmasking such an ideology requires placing such ideas in their historical and social context".

However, it should be noted that ideology is not to be understood in its pejorative and unsavoury connotation alone, for as it is stated earlier in the paper, that it (ideology) is a set of ideas and beliefs woven around the state and these ideas and beliefs "form the basis or foundation of political movement" and action "whether this is a movement we approve of or not". The problem is not really in adoption of ideology, but the important point is that whatever ideology that is adopted must be tailored towards transforming the state for some desirable ends and for the benefit of the citizenry.

Now turning to the Nigerian Policy on Education and the Second National Development Plan discussed above, one notices in both Plan and Policy (henceforth) what looks like an ideology for Nigeria. In the Plan there is an expression on the five main objectives, which include, among others, a pursuit of a free and democratic society, a just and egalitarian society. The Policy is acknowledged by the Government as an instrument for achieving the objectives. But the question is: what kind of economic system is Nigeria pursuing? What is the philosophy of Nigerian education? In order to address these questions, we only need to say that Nigeria since it became a sovereign nation and through the activities of the political and military class have purported to be pursuing one form of economic ideology or the other. The political parties that emerged before and after the exit of the British colonial administration and attainment of independence in 1960 were divided along ethnic lines. The three main political parties included the National Council of Nigeria and the Cameroons (N.C.N.C), the Action Group (A.G) and the Northern Peoples Congress (N.P.C) represented the three dominant ethnic groups in Nigeria namely; Igbo, Yoruba and Hausa-Fulani respectively. Since these parties were erected along ethnic divides, their leadership believed that they could win election by canvassing ethnic and tribal sentiments. For instance the N.C.N.C. and the A.G. touted "pragmatic socialism" and "democratic socialism" respectively, as the basis for the transformation of the country. The N.P.C was unapologetic in its defense of the overall interest of the Northerners. So what is obvious from the ideologies of these parties is that, apart from being skewed to favour and protect the economic, political and cultural interests of their leaders, they were not properly articulated to undergird the development agenda of the nation in order to extricate it from its over dependence on foreign economic system, contrary to what is stated in the Plan as the five main national objectives. This point is succinctly stated by Dipo Irele thus;

... the main political parties ideologies... did not take cognizance of the objective condition of the Nigerian masses in their ideologies. Further, these parties' ideologies or programmes were not tailored to extricate the Nigerian economy from its neo-colonial dependency to a self-reliant one. The parties' ideologies reflected the basic interest of the ruling class in Nigeria. The socio-economic system fostered exploitation and inequality in the social formation... and the various parties programmes did not have egalitarian ideal. (pp. 24-25). 
Like the ideology discussed above, the National Policy on Education, is criticized because it lacks a clear-cut philosophy of education. The strong point of the critics of the policy is that, at the moment, Nigeria, according to Fayemi as quoted by Akinsanya (2013: p. 220) 'cannot boast of a philosophy of education. Thus it is their contention that what is stated in the policy can hardly pass as philosophy of education in the strict sense of the term. This point is well taken by Nduka (2006: p.142) when he states that;

.... what now passes as a philosophy for Nigerian education is a non-starter in the philosophical stakes. At best it is a mythology of aims, goals and objectives lacking clarity, coherence and consistency. The basic problem arises from the fact that as a philosophy of education for a particular society it does not address itself squarely to the basic question: what type of society are we setting out to build? Is it a semi-religious oligarchy or a secular state, traditionbound or scientifically oriented, capitalist or socialist... elitist or egalitarian and so on?

Nduka may have come to this conclusion because of his understanding that 'philosophy of education is nothing if it is not primarily concerned with a critical study or enunciation of well-rounded theories of society and reality in general and how the underlying logical, epistemological, axiological and metaphysical principles impinge on educational practice (pp.142-143). What emerges from the discussion thus far is that there are some noticeable inconsistencies and contradictions in what is stated in the policy and the realities on ground. As it is adumbrated above, the Policy is intended to, among other things, inculcate some positive values in the citizenry like moral and spiritual values in interpersonal and human relations; respect for the worth and dignity of the individual'. Again, one of the five national objectives as enshrined in the Plan is a pursuit of "a just and egalitarian society".

These propositions seem fine and unassailable, but what Nigeria carries out in practice is a clear departure from what is stated in the document. For instance, the belief in achieving "a democratic and egalitarian society" is faulted by the fact that the economic system operational in Nigeria is capitalist oriented with the means of production concentrated largely in private hands. Again, the political scene is characterized by bitter struggle for power and violence bothering on tribal, ethno-sectarian and other clannish sentiments. This is also true of the political situation in Nigeria during the First Republic, which prompted Irele to say;

The political scenario after independence was characterized by unbridled sectionalism or tribalism by the main political parties. For instance, the A.G. espoused the notion of cultural nationalism. It believed that political stability could be achieved only if the ethnic groups that make up Nigeria were grouped together to form a single selfadministering political units (p. 22).

Further he submitted that "the strategy adopted for the development of Nigeria has not made a perceptive, scientific analysis of the Nigerian society and therefore no transformation of the society has taken place in terms of the 'good life' and raising the quality of life of the people". ( $p$. 30).

Also, the Policy affirms the imperative of a training in 'moral and spiritual values' with a view to "preparing the individual for useful living within the society". However in practical terms, there is no mechanism that is instituted for the teaching of moral education at all levels of Nigerian education system. Rather, what one finds is an emphasis on religious instruction, which is made an optional elective at the primary and secondary levels. For, the curriculum of moral education ought not be confused with that of religious knowledge. Whereas the former emphasizes the critical and rational analysis of issues, the latter teaches dogma through the means of indoctrination. Still, the definition and meaning of moral education can be deduced from the work of Bamisaiye (1989: p.67) when she says;
Moral education is the intellectual development of a person with a view to making him psychologically disposed to use his knowledge according to principles of overriding social welfare.

Another definition of moral education, which is not too dissimilar with the one above is given by 
Suleiman as quoted by Akinsanya (2013: pp.209210) thus;

Moral education, which is the possession of the knowledge and teachings of moral philosophy, is a means to develop an individual intellectually in line with the afore-said principles of right and wrong conducts in order to endow him with psychological ability to use his knowledge to achieve a balance in interpersonal relationship with other individuals and groups.

What is common in the two definitions given above is the intricate connection between ethics or moral theory, education and psychology. To be sure, ethics and education are normative disciplines since they prescribe what ought to be and are usually treated as an end in themselves, though sometimes might be considered as a means to the transformation of the society in terms of socio-economic and political development. This idea is stated in the 'introduction' of the Policy as "education in Nigeria is an instrument "par excellence for effecting national development". Psychology (developmental) on its own informs us about the different stages or "periods of moral development in children and young adults".

Then education as conceived in the Policy is geared towards "developing and inculcating proper values for the survival of the individual and society". But the question is: what are values? Although it is not clearly stated in the Policy, but values for our purposes here "are what is good or thought to be good, what is desirable or thought to be desirable' (Omoregbe, 1993: p.68). For instance calling an action or conduct right, or wrong; good or bad, virtuous or vicious simply means that it leads to a result which is good and elicits approval, and conversely saying that an action or conduct is wrong or bad or vicious means that one disapproves and condemns the action. Also implicit in any assessment of moral actions is the provision for alternatives, volition, choice, responsibility, freedom etc.

Now the question is: can virtues be taught? This question is usually asked when the issue of moral education is being discussed. In order to do justice to this question, we must first come to terms with Aristotle's idea of virtue. For Aristotle was the first philosopher to give an extended treatment of virtue in his book the
Nicomachean Ethics, though Plato made allusions to it in his Dialogues. Aristotle takes such concepts like justice, piety, courage, truthfulness, good, honour' etc as virtuous. Aristotle as quoted by Macintyre (1981: p. 139) defines virtue as precisely those qualities the possession of which will enable an individual to achieve eudemonia and the lack of it will frustrate his movement towards the telos. For Aristotle, according to Macintyre "every activity, every inquiry, every practice aims at some good, for by the good or a good, we mean that at which human beings characteristically aim. There are two kinds of virtue namely, intellectual virtue and virtue of character. Both virtues, apart from tending towards an end, are learnt or acquired through "teaching and habitual exercise". This point is well taken by Macintyre when he says;

We become just or courageous by performing just or courageous acts; we become theoretically or practically wise as a result of systematic instruction. Nonetheless, these two kinds of moral education are intimately related. As we transform our initial naturally given dispositions into virtues of character, we do so by gradually coming to exercise those dispositions... (pp. 144-145).

As a post-Aristotelian, Macintyre extensively expounded on Aristotle's theory of virtue and relating it to concrete situations than Aristotle or other philosophers before him. The idea of practice features prominently in Macintyre's understanding of virtue. By practice he means;

Any coherent and complex form of socially established cooperative human activity through which goods internal to that form of activity are realized in the course of trying to achieve those standards of excellence which are appropriate, and partially definitive of that form of activity.... (p:175).

Understandably, Macintyre's idea of practice is equivalent to Aristotle's notion of praxis', which he takes to be activity that is performed for the sake of it or has an end in itself as opposed to poesis, which is taken to mean an activity that is good as a means to an end or goal (Ekennia, 2000 ; p.38). Furthermore, Macintyre gives a definition of virtue by saying that a virtue is an acquired human quality the possession and 
exercise of which tends to enable us to achieve those goods which are internal to practices and the lack of which effectively prevents us from achieving any such goods" (p.178).

The picture that emerges in the discussion of virtue is the emphasis on training, practice, participation, relationship and social institution. For an illustration of this, Macintyre shows how a child who plays the game of chess repeatedly will acquire certain skills and competencies that will enable him or her to excel in whatever way the game of chess demands '(pp. 175-176). By internal goods, Macintyre means those goods internal to the practice which cannot be had in any way but by playing chess or some other game of that specific kind. One striking quality of internal goods for Macintyre as quoted by Ekennia is that they can only be identified and recognized by the experience of participating in the practice in question. To this effect, those who lack the relevant experience are incompetent thereby as judges of internal goods (Ekennia, 2000:p.5). Again, for Macintyre, in Ekennia (p.5) "social action or community action is important in any practice and may require certain virtues like truthfulness, justice, and courage for their execution without which practice cannot be sustained. Macintyre seems to reject the view that practices are the same in all cultures. Rather, "it is for a community to select those practices the execution of which will enable it to attain its goal or good". (p.4). Those human activities that would come within the context of Macintyre's definition of practices include, game of football, chess, architecture, farming, painting, music, physics, chemistry, biology, family life (Macintyre, p.175). This activity is what he calls internal good' as opposed to 'external good' which is performed for "prestige, status and money" (p.176). There is a necessary connection between our treatment of virtue and education. Education as we hinted at above is, following Osokoya as quoted by Akinsanya, the leading out of the in-born powers and potentialities of the individuals in the society and acquisition of skills, aptitudes and competencies necessary for selfreliance and for coping with life's problems' (pp. 96-97). Still Osokoya in the essay already cited, argues that traditional education in Nigeria was functional since it "was generally for an initiation into the society and a preparation for Adulthood" with its method of teaching based on practical participation in for example, hunting, ceremonies, rituals, dancing, fishing, drumming, racing, study of local history, plants and animals, poetry, reasoning, riddles, proverbs, taboos, moral and spiritual values (p.55).

\section{Research Questions}

The following questions will pre-occupy us in this study:

i. Are lecturers, students and their parents responsible for indiscipline in tertiary institutions?

ii. Is the society responsible for disciplinary problems in institutions of higher learning in Nigeria?

iii. Are inadequate facilities and the quality of teaching responsible for the problem of indiscipline on the campuses?

iv. What are the over-all implications of indiscipline and gross misconduct on the nation's higher education

\section{Methods}

This study employs the conceptual, descriptive and reconstructive method. Essentially, it attempts to collect information on one of the fundamental problems confronting the nation's tertiary institutions - the problem of indiscipline. The data for the study were obtained from questionnaire and commentaries from a cross section of the Newspapers and tabloids. The researcher decided to make use of the questionnaire method to elicit the opinions of students and lecturers in the selected University because it is not only flexible' but also has the potentials of eliciting responses from a broad range of issues. Two sets of questionnaires were designed and distributed each to students and lecturers. In all two hundred (200) copies of the questionnaires were distributed in the following order, Forty (40) copies each were given to students in Departments of Philosophy, History, Teacher Education and Physics.

In the questionnaires, respondents were required to say to what extent certain behaviour have been in their character since their admission or assumption of duty in the University as appropriate. The respondents were instructed to tick any of the three options $P, U N$ and the keys for these options were given as $P=$ in my character $\mathrm{U}=$ undecided, $\mathrm{N}=$ Not in my character. The responses were later grouped into those that accept and those that reject such behaviour as being in their character.

\section{Sampling Technique}

This research was originally intended to cover a few institutions of higher learning in the 
country. But due to time and financial constraints, it is limited to the University of Ibadan. The choice of this university is informed by two basic reasons. Firstly, the University is where the researcher is currently working as a lecturer and therefore has a daily and first-hand experience of students' behaviour pattern. Secondly, the choice of the University was made in the understanding that the findings of the study will serve as almost a true reflection of the situation in other campuses. Here, the population group consists of students and lecturers in four Departments from three faculties.

The departments and faculties above were carefully chosen because of their long years of establishment and students size.

\section{Analysis}

The data collected were subjected to statistical analysis, employing both descriptive and inferential. The responses to the theme on the questionnaire were scored based on a threepoint scale. Cross tabulation and chi-square of measures were taken to analyse the data collected. On the basis of this therefore, it was possible to determine the particular number of students and lecturers accepting or rejecting a certain attitude or behaviour as being in their character.

Research question 1: Are lecturers, students and their parents responsible for indiscipline in tertiary institutions?

\begin{tabular}{|c|c|c|c|c|c|c|c|}
\hline \multirow[t]{2}{*}{ Variables } & \multicolumn{3}{|c|}{ Response format } & \multicolumn{4}{|l|}{ Total } \\
\hline & $P$ & $U$ & $\mathrm{~N}$ & & $x^{2}$ & df & Significance \\
\hline $\begin{array}{l}\text { Comes to lecture(s) late or not } \\
\text { coming at all }\end{array}$ & $14(15.70)$ & $4(4.50)$ & $71(79.80)$ & $89(100)$ & & & \\
\hline $\begin{array}{l}\text { Having to wait for a while in the class } \\
\text { for the lecturers }\end{array}$ & $5(5.40)$ & $8(8.70)$ & $79(85.90)$ & $92(100)$ & & & \\
\hline Rude to lecturers and fellow students & $1(1.10)$ & $2(2.20)$ & $87(96.70)$ & $90(100)$ & & & \\
\hline for submission & $5(5.6)$ & $15(16.7)$ & $70(77.8)$ & $90(100)$ & & & \\
\hline $\begin{array}{l}\text { assignments do not bother me } \\
\text { Belonging to weird or secret societies } \\
\text { and using same to terrorize fellow } \\
\text { students and intimidate lecturers }\end{array}$ & $3(3.30)$ & $8(37.0)$ & $81(88.0)$ & $90(100)$ & 34.017 & 8 & 0.000 \\
\hline Total & $28(6.2)$ & $37(8.2)$ & $388(85.7)$ & $453(100)$ & & & \\
\hline
\end{tabular}

The table shows respondents' views on whether or not lecturers, students and their parents are responsible for indiscipline in tertiary institutions. $80 \%$ of the respondents chose that coming late to lecture or not coming at all was not in their character. Also, $85.9 \%$ of the respondents chose that waiting for a while in the class for the lecturers was not in their character. Most of the respondents that are $97 \%$ are not rude to lecturers and fellow students. $78 \%$ of the respondents do not bother about deadline for assignment submission. The implication of the above result shows that all the variables tested are significant because the significance level of 0.00 is $>0.05$ level of significant.

Research question 2: Is the society responsible for disciplinary problems in institutions of higher learning in Nigeria?

\begin{tabular}{|c|c|c|c|c|c|c|c|}
\hline \multirow[t]{2}{*}{ Variables } & \multicolumn{3}{|c|}{ Response format } & \multirow[t]{2}{*}{ Total } & \multirow[b]{2}{*}{$x^{2}$} & \multirow[b]{2}{*}{ df } & \multirow[b]{2}{*}{ Significance } \\
\hline & $P$ & $U$ & $\mathrm{~N}$ & & & & \\
\hline $\begin{array}{l}\text { Engagement in examination } \\
\text { malpratices } \\
\text { impersonation, }\end{array}$ & $10(11.1)$ & $20(22.2)$ & $60(66.7)$ & $90(100)$ & & & \\
\hline
\end{tabular}


sniffing, swarping of answer scripts etc

Heavy consumption of $2(3.3) \quad 1(1.7) \quad 57(95.0) \quad 90(100)$ alcohol, medicine and other hard substances.

Initiating and participating in riots

Use of foul or gutter language and calling people names

Mutilation of books in the library (such as tearing off and defacing vital portions of books and journals)

Total

10(11.1) 10(11.1) $70(77.8) \quad 90(100)$

$1(1.1) \quad 2(2.2) \quad 86(96.6) \quad 89(100)$

$33(7.9) \quad 43(10.3) \quad 343(81.9) \quad 419(100)$

The above table shows respondents' opinion on whether society is responsible for disciplinary problems in institutions of higher learning in Nigeria. $67 \%$ of the respondents chose that engaging in examination malpractices such as impersonation, giraffe, sniffing, swapping of answer scripts was not in their character. While $95 \%$ of the respondents chose that heavy consumption of alcohol, medicine and other hard substances was not in their character. $78 \%$ of the respondents rejected initiating and participating in riots or use of foul or gutter language and calling people names as being in their character respectively. Meanwhile, $89 \%$ of respondents claimed that the attitude of mutilation of books in the library such as tearing off and defacing vital portions of books and journals was not in their character. Therefore, the $X^{2}$ value shows that 0.00 is $>0.05$ level of significant. However, the result shows that there is a significant difference between students involved in examination malpractice, alcohol taking and use of foul or gutter language in calling other colleagues in the class.

Research question 3: Are inadequate facilities and the quality of teaching responsible for the problem of indiscipline on the campuses?

\begin{tabular}{|c|c|c|c|c|c|c|c|}
\hline \multirow[t]{2}{*}{ Variables } & \multicolumn{3}{|c|}{ Response format } & \multicolumn{4}{|l|}{ Total } \\
\hline & $P$ & $U$ & $\mathrm{~N}$ & & $x^{2}$ & df & Significance \\
\hline $\begin{array}{l}\text { Indecent dressing and } \\
\text { unnecessary sexual postures }\end{array}$ & $1(1.1)$ & $3(3.3)$ & $86(95.6)$ & $90(100)$ & & & \\
\hline $\begin{array}{l}\text { Putting up unfriendly behaviour } \\
\text { and ignoring instruction from } \\
\text { lecturers }\end{array}$ & $5(5.4)$ & $1(1.1)$ & $86(93.5)$ & $92(100)$ & & & \\
\hline $\begin{array}{l}\text { No time for leisure or extra- } \\
\text { curricular activities }\end{array}$ & $3(3.3)$ & $6(6.7)$ & $81(90.0)$ & $90(100)$ & 285.915 & 8 & 0.000 \\
\hline $\begin{array}{l}\text { Tells lies in order to gain favour } \\
\text { or escape being penalized }\end{array}$ & $8(9.0)$ & $6(6.7)$ & $75(84.3)$ & $89(100)$ & & & \\
\hline $\begin{array}{l}\text { Queuing up and waiting for your } \\
\text { turn, at bus stops, cafeteria, etc }\end{array}$ & $75(82.4)$ & $6(6.6)$ & $10(11.0)$ & $91(100)$ & & & \\
\hline Total & $92(20.4)$ & $22(4.9)$ & $338(74.8)$ & $452(100)$ & & & \\
\hline
\end{tabular}

The above table depicts respondents' views on whether or not inadequate facilities and the quality of teaching were responsible for the problem of indiscipline on the campuses. $95 \%$ of the respondents chose that indecent dressing and unnecessary sexual postures were not in their character and therefore were causing problem of indiscipline on the campuses. Also, 
$94 \%$ of the respondents chose that putting up unfriendly behaviour and ignoring instructions from lecturers was not in their character, while $90 \%$ do not use their time for leisure or extracurricular activities. However, most respondents, that is, $89 \%$ and $91 \%$ respectively rejected as not in their character to tell lies in order to gain favour or escape being penalized and queuing up and waiting for their turn at bus stops, cafeteria. The implication of the above result shows that all the variables tested are significant because the significance level of 0.00 is $>0.05$. Therefore, there is a significant difference between the respondents' opinion on inadequate facilities and the quality of teaching responsible for the problem of indiscipline on the campuses.

Research question 4: What are the over-all implications of indiscipline and gross misconduct on the nation's higher education?

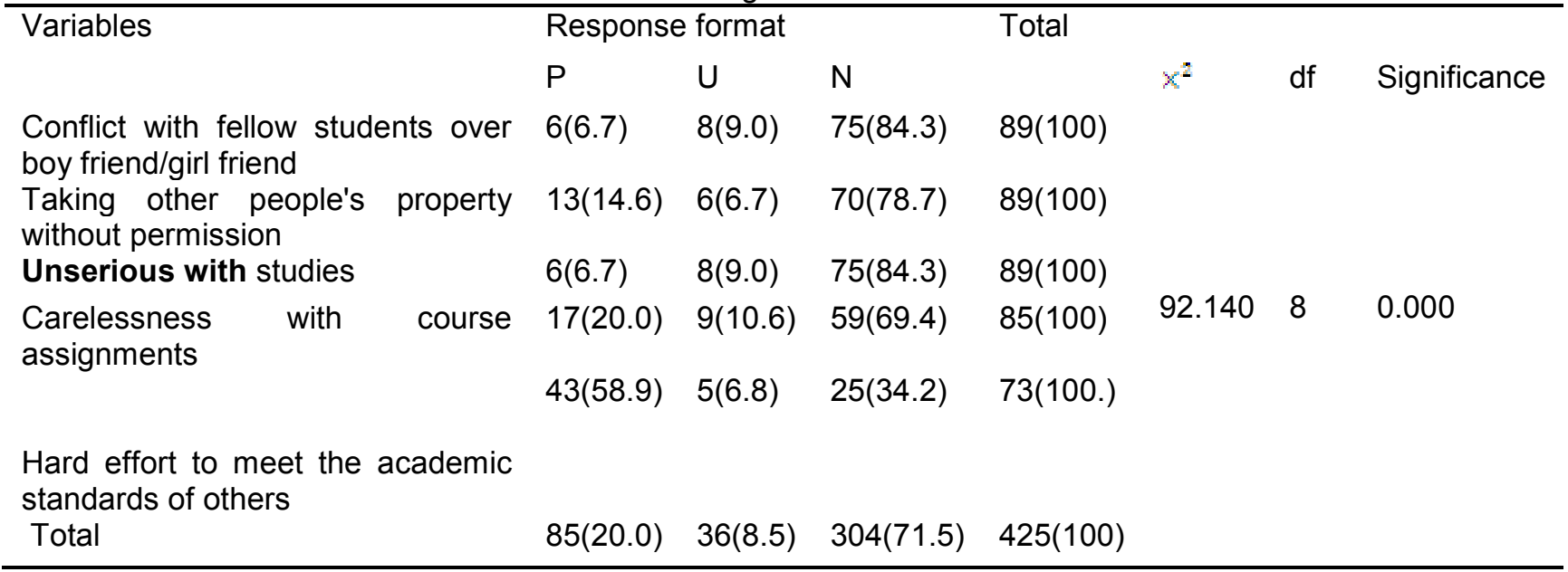

The result from the above table shows over-all implications of indiscipline and gross misconduct on the nation's higher education. $84 \%$ of the respondents rejected engaging in conflict with fellow students over boy friend/girl friend. Also, $78 \%$ of the respondents chose that taking other people's property without permission was not in their character while $84 \%$ and $69 \%$ of respondents claimed it was not in their habit to be unserious with studies and carelessness with course assignments respectively. The implication of the above result shows that all the variables tested are significant because the significance level of 0.00 is $>0.05$ level of significance. Therefore, there is a significant difference between the respondents' opinion on the over-all implications of indiscipline and gross misconduct on the nation's higher education.

\section{Summary of Major Findings}

Based on the analysis of the result of above, one can make the following deductions:

1. Majority of the respondents (i.e. students and lecturers) rejected as being in their character the habit of coming late for lectures or missing classes out rightly. So, on this item, both students and lecturers can be said to be alive to their responsibilities.

2. On the question of examination malpractices, most students rejected as not in their character to engage in such act because of its consequences, which is failure or expulsion or rustication. That is to say that a student will necessarily prepare and sit for his examinations without indulging in malpractices if given the proper guidance and training. This, no doubt, corroborates the lecturers' response that logical and proper presentation of their lectures is in their character.

3. On the issue of dressing, opinions were divided because it is arguable what constitutes decent dressing, and it also depends on individual values. A corollary to this is the issue of sexual harassment, which both students and lecturers disagreed as being in their character although some lecturers believe that no 
serious academic activity can take place in unfriendly and hostile atmosphere. By and large, all the disciplinary offences for which the students and lecturers could be accused of were rejected as being in their character according to the results of the tables. So, the students as well as lecturers have inherent tendencies to be disciplined and this is borne out of the fact that they are mature people and as claimed earlier there is a correlation between discipline and maturity.

\section{DISCUSSION}

The opinions expressed by both students and lecturers on the question of whether they come or skip lectures show that there is consensus that they come to lectures except for serious unavoidable reasons. This result underscores the point that students and lecturers have never abandoned their primary responsibilities. However, the negative implication of this is that there is a gradual depletion or pressure on the few available facilities in the schools. This point is confirmed by Osokoya (1995, p. 96-97) when he said that 'students enrolments at the Universities increased astronomically over the years, and similar expansions have occurred in Colleges of Education and Polytechnics." The tables above show that both categories of respondents widely agree on the question of personal disposition towards each other.

That there is a general agreement here reveals that a proper academic activity can only take place in a friendly environment. Also there was a concordance of opinions on the question of indecent dressing and sexual harassment. Even though, it is still highly debatable what constitutes indecent dressing and the precise meaning of sexual harassment, majority of the respondents rejected them as being in their character.

However, opinions seem divided on the issue of examination malpractices, whereas some denied ever engaging in such practice, others remained undecided. Although the percentage of those in the latter group say that students do not engage in examination malpractices. What needs to be done is to attempt to establish the possible causes of such act. One of such is inadequate teaching facilities and the over-emphasis on 'one shot' examination which introduces fear and panic in the students instead of continuous assessment. The importance of continuous assessment and tests is elaborated by Awoniyi $(1979$, p.5) when he said "it (test) is now very much a part of teaching and learning, and should not be seen either as a punishment or an end-of-term jamboree. It is a consistent and integral part of every lesson or course." It is shown that students' responses to the question on their membership or otherwise of anti-social organizations such as secret cult varied. Whereas majority frowned at secret cult activities and would never have anything to do with that, yet others accepted.

Even though, the percentage of those agreeing is small, we can use it to delineate the obvious fact that the phenomenon of secret cult activities on the campuses is not only a reality but disturbing to the school authorities and government. Admittedly opinions are still divided on the possible causes of this anti-social behaviour, but recent studies have shown that parents may have abandoned their traditional role as agents of socialization for their children. It is claimed that "children are not blind automata, they learn through direct experience by observing others or by being told", (Okorie, 1989, p.28). Thus, parents should guard their utterances and actions, otherwise they might inadvertently be turning their apparently innocuous children into a rebel or social misfits through their actions. Also, there is need for parents, organized private sectors, and government to provide the necessary fund which "would assist schools to acquire sports and recreational facilities, canteen and laboratory equipment" for students and lecturers to relax themselves. It is claimed that 'all work and no play makes Jack a dull and stubborn boy. There is need for students to engage in leisure and recreational activities as such would improve both their cognitive and emotional development.

Majority of the lecturers accepted making political remarks, if by that we mean constructive and critical analysis of contemporary issues in the country and beyond. The school is a subsystem of the larger society and so lecturers cannot remain indifferent and aloof to the urgent business of the state.

\section{CONCLUSION}

It was stated earlier that there is now what seems like a general indiscipline in our school system, especially tertiary institutions and this has assumed an alarming proportion. Now the general impression is that the lecturers may 
have abandoned their statutory responsibilities as role models and trainers in pursuit of material wealth. Some blame the parents for the indiscipline of their children and the argument is that if he/she (child) is given the proper training right from birth it will reflect in his/her outlook later in life. So what the present study attempts to do is to locate the source of the problem and proffer solutions.

Based on the findings of this research, it is shown that although, some of the students and lecturers could engage in certain morally reprehensible acts, but that is true of all human beings anywhere. Since such acts of misbehavior are learned through experience and by interaction with peers, it is still through learning process that they could be corrected. It is the submission of this paper that government should design a comprehensive policy with a clearly defined programme on moral education, which is fashioned on a well articulated social ideology for Nigeria. The programme on moral education, which is theoretically and practically based similar to those in traditional education, provides an enduring basis for addressing the myriad of challenges facing Nigerian Universities in particular and education in general. The paper also submits that an enabling environment should be provided for both lecturers and students through improved conditions of service for staff and scholarship grants and awards to deserving students as appropriate.

\section{REFERENCES}

Achebe, C., 1993. The Trouble with Nigeria Enugu Fourth Dimension Publishing Co. Ltd.

Adebayo, Aduke., 2005. Revisiting the academic Tradition, 28th Postgraduate School Interdisciplinary Research Discourse, Ibadan; Postgraduate School University of Ibadan.

Ajayi, K., 1990. 'The War Against Indiscipline (WAI) and its Implications for the Nigerian School System' in K. Ajayi and T. Ajayi (eds) New Perspectives in Nigerian Education Ibaden Vantage Publishers Ltd.

Akinpelu, Adelayo J., 2005. Essays in Philosophy and Education Ibadan: Strling - Horder Publishers.
Akinsanya, P. O., 2013. Philosophy as Education, ljebu-Ode, Nigeria, PATT Publishers.

Awoniyi, T., 1979. Principles and Practice of Education, London, Hodder and Steughton.

Ayodele-Bamisaiye., 2009. What is Man, That we should Educate Him? Ibadan: Ibadan University Press.

Bamisaiye, R., 1989. A Practical Approach to Philosophy of Education Ibadun AMD Publishers.

Barrow, R., 1979. Moral Philosophy for Education, London, Allen and Unwin.

Coombs, P. H., 1985. The World Crisis in Education, Oxford (O.U.P)

Downce, R. S. et.al., 1974. Education and Personal Relationship, A Philosophical Study, London, R. K. P.

Ekennia, J. N., 2000. African Modernity Crisis Benin Nigeria: Barloz Publishers Inc.

Federal Government of Nigeria., 2004. National Policy on Education: Lagos: Federal Government Press.

Hoffman, J and Graham, P., 2006. Introduction to Political Ideologies London: Pearson Education Ltd.

Irele, D., 1993. In the Tracks of African Predicament Philosophy and Contemporary Socio-economic and Political Problems of Africa, Ibadan: Options Book and Information Services.

Jenkins, W. K., 1978. Policy Analysis: A Political and Organizational Perspective London: Martin Robertson.

Jimoh, S. A., 1987. School Discipline in the Nigerian Journal of Guidance and Counselling. 3, (1\&2):

Macintyre, A., 1981. After Virtue a Study in Moral Theory, London: Gerald Duckworth \& Co. Ltd. 
Madunagu, E., 1983. 'The Structural Courses of indiscipline and Corruption in Nigeria, paper presented at the National /Seminar on Indiscipline and Corruption.

Maitama Sule., 1987. Corruption and Indiscipline in Nigeria, a paper presented at the launching of MAMSER in Kwara State

Marx, K and Engels, F., 1970. The German Ideology, London: Lawrence and Wishart.

Mayor, F., 1980. A History of Educational Thought Oxford, OUP.

Mussen, P. H. et al., 1979. Child Development and Personality, New York: Harper and Row Publishers.

Nduka, O., 2006. The Roots of African Underdevelopment and Other Essays., Ibadan: Spectrum Books Limited.

Nduka, Otonti, 2006. The Roots of African Underdevelopment and Other Essays, Ibadan: Spectrum Books Ltd.

Niblett, W. R., 1963. Moral Education in a Changing Society London, R K.P.

Okorie, D. C., 1989. 'National Discipline A psychological Approach' in National Orientation Movement D.C.E. Ugwuegbu (ed.) Federal Ministry of Information and Culture, DWAIRNOM Division.

Olaniyi, J.O., 1998. Foundations of Public Policy Analysis: Ibadan: Sunad Publishers Limited.

Olurode Lai., 2004. Campus Violence as Precursor to Intellectual Atrophy in Lai Olurode and Omololu Soyombo (eds) Readings in Campus Violence Lagos: John West Publication Ltd.

Omoregbe, J., 1993. Ethics, a Systematic and Historical Study, Lagos, Nigeria: Joja Educational Research and Publishers Ltd.

Osokoya, I. 0., 1995. History and Policy of Nigerian Education in World Perspective Ibadan: AMD Publishers.
Osokoya, I. O., 1989. History and Policy of Nigerian Education in World Perspective: Ibadan: AMD Publishers.

Peters, R. S., 1973. The Concept of Education London Routledge and Kegan Paul.

Piaget, Jean., 1965. The Mural Judgment oil/re Child (trans.) Marjorie Gabain, New York: The Free Press.

Report of the Committee on War Against indiscipline and Corruption.

Sharkansky, L., 1978. Public Administration: Policy Making in Government Agencies, Chicago: Rand McNally College Publishing Company.

Skinner, B. F., 1971. Beyond Freedom and Dignity York Bantham Books.

Sofola, J. A., 1978. African Culture and the African Personality, What makes an African Person African, Ibadan, African Resources Publishers Co.

Umaru Aliyu., 1996. Corruption and Immorality in Nigerian Society (causes and possible solutions), a paper presented at the Technical Students Association Week Kaduna Polytechnic 30th May.

West Tam David., 1996. Discipline in Nation Building in The Guardian July 7, P.A11. 